\title{
Rationalization of Action Process on Fishermen Society
}

\author{
${ }^{1}$ Awaluddin Hamzah, ${ }^{\text {i }}$ Muhaimin Hamzah, ${ }^{1}$ Hartina Batoa, ${ }^{2}$ Abdul Gafaruddin, ${ }^{2}$ Muh. Aswar Limi, ${ }^{2}$ Syamsul \\ Alam Fiyka, ${ }^{2}$ La Ode Kasno Arif
}

${ }^{1}$ Department of Agricultural Extension Faculty of Agriculture, Halu Oleo University of Kendari

${ }^{2}$ Department of Agribusiness Agricultural Department Faculty of Agriculture Halu Oleo University of Kendari

${ }^{\mathrm{i}}$ Department of Aquaculture Faculty of Aquaculture and Marine Science, Halu Oleo University of Kendari

Correspondence Author: Awaluddin Hamzah, Department of Agricultural Extension Faculty of Agriculture, Halu Oleo University of Kendari.

E-mail:- awal.hamzah@gmail.com

Received date: 15 August 2019, Accepted date: 30 September 2019, Online date: 28 October 2019

Copyright: (C) 2019 Awaluddin Hamzah et al., This is an open-access article distributed under the terms of the Creative Commons Attribution License, which permits unrestricted use, distribution, and reproduction in any medium, provided the original author and source are credited.

\begin{abstract}
The high social differentiation in industrial society is strongly influenced by machine, capital, and expertise in the ongoing work process, which in turn classifies industrial workers based on mastery of the elements of production. This study can provide recommendations for a model of empowerment of fishing communities based on patronage institutions that are experiencing dynamics. The location of this research study was chosen purposively based on the consideration of access to enter the area, personal relationships between researcher and prospective informants (respondents) had been well established; the majority of the people in this area worked as fishermen. The very prominent institutions were patron-client relations system. Rational actions (consideration of effectiveness and efficiency) of fishermen were seen in the consideration to create innovation in terms of catch technology. This was performed to increase the production and income of fishermen. However, rationalization did not develop in terms of reinvestment, even though the Punggawa (Indonesian terms - especially Bugis society - of capital owners) was actually able to do it. In addition to the availability of fishing support institutions, fishermen could also concentrate fully on fishing activities until at the time fish brought to land. The growing rationalization of actions has not been able to move the economy of the fishing community as a whole. This is also one of the factors that causes patron-client institutions to continue to exist (survive) in the midst of society.
\end{abstract}

Keywords: Rationalization, Fishermen, Industrial, Patronage

\section{INTRODUCTION}

Indonesia has abundant fisheries resources. According to Roberts et al. in Hasani (2012), the Indonesian sea is one of the highest centres of diversity in the world, even as global marine biodiversity. This is not surprising because Indonesia is the largest archipelagic country in the world which has 13,466 islands with the second-longest coastline in the world after Canada with the length of 99,093 kilometres (BIG 2013). More than 14 million people or approximately $7.5 \%$ of the total population of Indonesia depend on activities in this area (DG KP3K in Hasani, 2012). Then around 26\% of Indonesia's total Gross National Product (GNP) is from marine and coastal activities and resources. This has led to the fisheries sector to be very important.

In general, fishermen or coastal communities are a group of people who are relatively left behind economically, socially, especially in terms of access to education and health services, and cultural compared to other community groups. Such perceptions are based on the results of direct observation of rehabilitation of the fishermen's lives or coastal community lives through understanding the results of academic studies. As the most significant maritime country in the world with abundant natural resource, the underdevelopment of fishermen's lives or coastal community lives that occurs indicating an error in the development strategy (Kusnadi, 2007).

The economic activity of fishers cannot be separated from the interaction between individuals and the internal ethnic groups. Internal communication of community in one ethnicity has caused social processes in the community itself. Geertz in Mubyarto et al. (1993) notes that in Indonesia, there are approximately 300 ethnic with their own cultures, and 250 different regional languages. The various tribes and ethnic inhabit the region with diverse geographical conditions and locations. Some tribes inhabit areas with mountain/highlands geographies so that people will live with cultural patterns, socio-economic systems that adjust to the geographical location. The life of highland communities, in general, is depending on farming and plantations. 
Citation: Awaluddin Hamzah, et al., Rationalization of Action Process on Fishermen Society. Australian Journal of Basic and Applied Sciences, 13(10): 93-98. DOI: $10.22587 /$ ajbas.2019.13.10.13

The community of Kampung Bugis before inhabiting the area around Rahandouna urban village, they settled around the area of Lapulu urban village. The local Bugis community moved in Rahandouna urban village together and inhabited the vacant land provided by the government for free around 1972. Initially, Bugis people/community who moved and inhabited the area around the Rahandouna urban village were as a whole or $100 \%$ Bugis tribe. Therefore, the area has since been more popular with the name Kampung Bugis.

At the time of industrialization, technology and information grow so fast in all sectors; it also affects social-economic activities, even shifting or removing local values, norms and institutions. In this case, according to Tjondronegoro, the mastery of tools has an impact on the emergence of a stratification process, control over resources, and various facilities will continue (Satria, 2001). As a result, stratification creates a polarization in social life. Whereas according to Hayami and Kikuchi (1987) the increase in the number of landlords due to the green revolution has not seen any polarization due to the strength of institutions and moral ties. The use of modern technology facilities according to Siahaan (Hamzah, 2013) has also forced farmers to think more rationally and commercially. These conditions ultimately diminish social obligations and the breakdown of community ties in the lives of farmers.

According to Rostow (1964), industrial transformation is characterized by an increase in Per capita income, which is the high economic growth is maintained. In addition, according to Ponsioen (1969: 163) industrial transformation is also characterized by a shift in investor-worker relations, from patron-client relations to contractual relations. This phenomenon sociologically indicates that acceptance of change has not institutionalized in the community; in terms of technical innovation, management organizations, or lifestyle.

This is related to the type of social action in a community that has not fully shifted from the type of prescriptive action to the type of elective action (Germam, 1981). On the one hand, the choice of action is tied to cultural traditions. Whereas, on the other hand, the choice of action refers to the individual authorities to appreciate the changes. In social interaction, or even further in the pattern of power distribution in community, the result of the lack of realization of social action is the existence of patron-client bonds, so that industrial compliance relations that have become the main characteristic of social interaction in industrial society have not been fully realized.

From the various descriptions, as well as the description of the research study, it becomes interesting that in era of modernization, technology, and information, it turns out that traditional institutions persist. Although in principle, various efforts both intentionally and unintentionally, these practices include patronage which still thrives in the community. This research study can provide recommendations for the fishermen empowerment based on dynamic patronage. Besides, research study on the social life of fishermen, especially patron-client in Southeast Sulawesi is still rarely conducted. So far, the research study of PatronClient of fishermen generally conducted on the society of Java, Sumatra, and coastal of South Sulawesi.

The main objective of this study is to study the process of rationalization of actions as one of the characteristics of industrial transformation carried out in fishing communities

\section{Statement of Problem}

Based on the description of the background explained in the introduction, the research question in this study can be formulated as "how does the process of rationalizing action as one of the characteristics of industrial transformation take place on the fishermen of Kampung Bugis?"

\section{LITERATURE REVIEW}

In the theory of modernization, the process of transformation towards industrial society can be explained through the theory of social differentiation, which states that the transformation towards industrial society is identical to the process of increasingly differentiating society. This explanation came from Durkheim's theory (1964) on the division of labor in society.

Structurally, Durkheim (1964) explained that in industrial society, the structure of labor was very complex and the division of labor was specialized, because in a community developed various types of labor and in each labor segment developed several divisions of labor. In the industrial society, the community is divided into various division of labor. Therefore, social heterogeneity becomes higher and cooperation between the division of labor is needed, so that interdependence in community is very high. according to Durkheim; this is a community with an organic solidarity type. The division of labor in the fishing industry community develops along with technological improvement. When using traditional technologies such as fishing rods and traps, there is no division of labor. The division of labor is only between men and women.

The high social differentiation in industrial society is strongly influenced by machine, capital, and expertise in the ongoing work process, which in turn classifies industrial workers based on mastery of the elements of production, resulting in professional, managerial, technical, and labor groups (Kerr, Dunlop, Harbison and Myers, 1994). Based on Triyakian (1992), in social change or modernization, there were two significant processes occurred, these are social differentiation and rationalization of action. These two processes determined the extent to which social change or modernization continued to be followed by community and avoidable from social pathology. In this research study assumed that social differentiation and rationalization of actions are factors that must be analyzed for its characteristics and balance of development.

Triyakian (1992) also concluded that the two processes did not take place linearly, but reverse process in the form of differentiation and in the form of derationalization for rationalization. It was recommended that social change or modernization observed from a dialectical approach between differentiation and rationalization and considering dediferation and derationalization as the process of reversing it. In this research study assumed that social differentiation and rationalization of 
Citation: Awaluddin Hamzah, et al., Rationalization of Action Process on Fishermen Society. Australian Journal of Basic and Applied Sciences, 13(10): 93-98. DOI: $10.22587 / a j b a s .2019 .13 .10 .13$

action were not only seen in terms of the characteristics and balance of development between the two but also in the process of reversing to the both of them in the form of differentiation and derationalization.

With such references, the development of investment, management, and technology in the community of traditional fishermen, will encourage the occurrence of social differentiation and rationalization of action. This allegation is based on the argument that the development of investment, technology, and management is a stimulant of social change in the context of industrial transformation. Social differentiation and rationalization of action are significant processes in social change, meaning that the development of investment, technology, and management will encourage social differentiation and rationalizing of action.

One indicator of industrial transformation is a shift in the form of industrial relations in it. Industrial relations shifted from the characteristics of patron-client relations to the characteristics of contractual relations (Ponsioen, 1969), from the characteristic of a multiplex relations (Work relations that take place repeatedly so as to grow relationships like family) to the characteristic of a simplex relations (an impersonal work relations with a working mechanism that refers to a market system) [Legg, 1983], or from the characteristics of moral-based relations to the characteristics of rationality-based relations (Popkin, 1979). In this research study, a shift in patron-client relations to industrial relations is used as an indicator of ongoing industrial transformation.

\section{RESEARCH METHODS}

\section{Location and Time of Research Study}

This research study was conducted in August 2018, in Kampung Bugis, Poasia Sub-District, Kendari, Southeast Sulawesi Province. In the Kampung Bugis area, in general, community depended on the fishing sector and their supporting jobs. In addition to the main job as fishermen, selling services became an alternative source of household economics especially during the fishing break season. Patronage in the location of research study varied the fishing activities and other social activities. In its development, there was a phenomenon that underlies the opinion that there had been a transformation of patronage on fishermen in location of the research study. The phenomenon was the presence of client originating from outside Kampung Bugis; there was not even a communal bond other than a work bond with patron. This greatly helped the researcher in obtaining the correct data regarding the dynamics of transformation of patron and client.

In its development, fishing activities as the main job of fishermen experienced the transformation of production facilities (mode of production) in the form of fishing gear and as a consequence of the development of community which needed fish catch both in quantity and quality. In each period, the use of production tools, patron-client relations in the communities of the two locations certainly experience the dynamics of change.

The purpose of this research study was to describe the various realities and social phenomena of fishermen, this research study used postpositivism approach with an interpretive approach based on the belief that humans were creatures that socially and symbolically formed and maintained their own reality. The interpretive approach began from the efforts to find an explanation of social or cultural events that were based on the perspectives and experiences of the person. The interpretive approach according to Gunawan (2013) was adopted from a practical orientation. This research study was qualitative research used to examine the condition of natural objects, in which the researcher was a key instrument, in other words explaining the facts through individual actions.

\section{Data Sources and Determination of Informants}

The process of collecting the data was performed through fishermen's household, both patron and client status as respondent units of research study. Other informants involved were the manager of activities, production, and community leaders. Community leaders were chosen with the status as people who understand even involved in production activities in every periodization of the use of production facilities.

\section{Informant Determination Technique}

To collect qualitative data, the determination of informants was based on initial information about residents involved in fishing activities, such as labor, traditional fishermen, fishermen, and fish traders. The information is mainly obtained from the instructions of the Village apparatus or the head of the neighbourhood. The informants interviewed were then asked about other residents who could be used as the next informants. In addition to the snowball technology like that, the researcher also determined the informants themselves from the results of interactions with residents in the research location.

The next consideration is the knowledge of informants regarding the history of institutional patrons and clients. The selection of informants is based on the principle of the subject who controls the problem, has data and is willing to provide complete and accurate information..

\section{RESULTS AND DISCUSSION}

Fishermen's income was closely related to the ability of fishery production and selling the fish. However, both of them could sometimes be dilemma for fishermen. In the season of fish with abundant catches, fish prices actually fell down. Whereas in the dry season, fish prices would rise. However, the relations of production and fixed income influenced each other. These results were obtained as a result of free market both in the market and the traders (Pappalele) who waited when the fishermen came back from the sea. This income was used for daily living needs as well as repairing to boats and replacing damaged fishing rods. 
Citation: Awaluddin Hamzah, et al., Rationalization of Action Process on Fishermen Society. Australian Journal of Basic and Applied Sciences, 13(10): 93-98. DOI: $10.22587 /$ ajbas.2019.13.10.13

Finance was managed by fisherman's wife as manager of fisheries household finances (RTP). Daily needs could be fulfilled because they only bought rice and vegetables because the fish were obtained from the catch besides being sold.

The development of patron-client relations between Punggawa and Sawi (Indonesian terms - especially Bugis society - of the borrower or worker or can also be called a laborer) also had implications for the emergence of rational economic relations, such as the relationship of accounts payable. The debt owed created a feeling of "discomfort" for Sawi to move to the Page group with another Punggawa. As a result, the nature of workers became semi-free workers. This relationship developed among fishermen.

Management development included fishing management, production management and marketing management. The development occurred was the change from fishing/individual to a group of business that formed a pattern of Punggawa-Sawi relations. Production management was characterized by the separation of household businesses and the reduced role of Punggawain land(owners) in terms of fishing activities and more to entrust these matters to the Punggawa in the sea. The management could not be separated from the nature of the object of the fishing and volume that could not be predicted with certainty. Likewise with the Sawi recruitment criteria that not only relied on communal relations but also members who were strong about their skills, in addition to honesty and sincerity of work. Thus, the phenomena was the formation of complex, structured, and hierarchical relationships. Briefly the development aspects of management can be seen in table 1 .

Table 1: Aspects of Development of Bugis Village Fisheries Management, 2018

\begin{tabular}{|c|c|c|c|}
\hline No & Aspect & Characteristic & Actor \\
\hline 1. & Structure & $\begin{array}{c}\text { a. increasingly complex, structured and hierarchical } \\
\text { b. individual business changes to group business management form a } \\
\text { pattern of Punggawa-Sawi relations. } \\
\text { c. structured in Punggawa of Land, Punggawa of Sea and Sawi }\end{array}$ & $\begin{array}{l}\text { Fishermen } \\
(\text { punggawa) }\end{array}$ \\
\hline 2. & $\begin{array}{c}\text { Production and marketing } \\
\text { management }\end{array}$ & $\begin{array}{l}\text { a. Production volume cannot be predicted. } \\
\text { b. The responsibility of production owned by Punggawa of sea. } \\
\text { c. Marketing responsibility for Punggawa of Land or special } \\
\text { institutions. } \\
\text { d. The Sawi recruitment criteria prioritizes "professional" workers }\end{array}$ & $\begin{array}{l}\text { Fishermen } \\
\text { (punggawa) }\end{array}$ \\
\hline
\end{tabular}

Structurally, Suriadi (2006) explained that in industrial societies, the structure of work was very complex and the division of labor was specialized, because in the community there were various types of work and in each work developed in various divisions of work. Because in the industrial society the community group was divided into various work divisions, so social heterogeneity became higher and cooperation between work divisions was needed. Therefore, interdependence in society was very high. This characteristic was typical of people with organic type of solidarity. The division of labor in the fishing industry community developed along with technological developments.

When using traditional technologies such as fishing rods and traps, there was no division of labor. The division of labor was only seen between men and women. The high level of social differentiation in industrial society according to Keer (Suriadi 2006) was strongly influenced by the involvement of machinery, capital, and expertise in the ongoing work process, which in turn classified industrial workers based on mastery of the production elements, so that it created professional, managerial, technical, and low-skilled workers.

The description concluded that the development of fishing technology had resulted in significant production volume. The surplus caused fishermen to develop their businesses and diversify businesses that could support the income and welfare of the fishermen themselves. With this, innovations in boat equipment and other equipment were developed by certain individuals in the community.

\section{Rationalization of Fishermen's Action}

Rational actions (consideration of effectiveness and efficiency) of fishermen were seen in the consideration to always create innovation in terms of fishing technology. This was performed to increase the production and income of fishermen. However, rationalization did not develop in terms of reinvestment, even though the Punggawa was actually able to do it. In addition to the availability of fishing support institutions, fishermen could also concentrate fully on fishing activities until at the time of fish lifted to the land. In fact, the provider of supporting needs was carried out by the state, namely the presence of Pelabuhan Samudera (PPS) in Kendari. The rationality shown by Bugis Village was instrumental rational (Weber, 2006) which was the ideal type of industrial society.

Rationalization interpreted by Weber (2006) as a process of emptying the world of magical and mystical influences. Magical and mystical influences (blending in with Islamic religious traditions) on the lives of fishermen in the Bugis village were still found even in a small percentage. The tradition of salvation and repulsion was still performed at the beginning of the fishing trip and when the fishes lifted to the land. Various beliefs and traditions of the Bugis Makassar people still coloured the fishing activities. In some parts of the ship there were objects believed to affect fishing activities.

Like most of Bugis Makassar fishermen, Punggawa-Sawi also believed that the position of the ship that would go to the sea could not be turned towards the fishing ground (figure 8). According to the informants (Punggawa and Sawi), this was done in order to get sailing safety and blessing of the fishing. Therefore, the concept of dialectic modernization by Tiryakian 
Citation: Awaluddin Hamzah, et al., Rationalization of Action Process on Fishermen Society. Australian Journal of Basic and Applied Sciences, 13(10): 93-98. DOI: $10.22587 / a j b a s .2019 .13 .10 .13$

rationalization and derationalization (Suriadi, 2006; Salman, 2006) occurred. Thus, Weber's understanding of the ideal type of society for the Bugis Village fishermen had not yet happened.

Theoretically, the economic commercialization was related to the economic structure, meaning that the economic institutions of the past Bugis Village fishing communities that formed could not be separated from the social structure and economic situation at that time (the application of technology before the implementation of Gae). In this era, the economic system of patronage was based on morality in the economic system of local fishermen which survived until the 1980s. At that time fishermen relied on guarantees and protection of patrons (investors and entrepreneurs from outside the region) to fulfill their subsistence needs, especially in times of crisis. As a mutual benefit, the fishermen were loyal followers who were ready to do whatever the work was given.

\section{CONCLUSIONS AND RECOMMENDATIONS}

\section{CONCLUSION}

Although rationalization (economic commercialization) took place in Bugis Village, it was not able to significantly change patron-client relations. This was due to the economic commercialization that was happening in the place. In other words, the rationalization of actions had not been able to move the economy of the fishing community as a whole. This was also one of the factors that caused patron-client institutions to exist (survive) in the midst of society.

\section{RECOMMENDATIONS}

The development of fishing communities should still pay attention to local institutions since it can be one of the pillars of the economy that must be maintained.

\section{REFERENCES}

Abernethy, C.L. 2002. Water Institution to Enhance Economic Development. Majalah Agricultural + Rural Developmet, No. 2 Tahun 2002.

Arief, A. 2015. Pemberdayaan Masyarakat Nelayan Melalui Pendekatan Kelembagaan Lokal (Studi Kasus Desa Pajukukang Kecamatan Maros Utara, Kabupaten Maros). https://www.scribd.com/doc/13134563.

Arifin, A 2014. The Patron-Client Relation In Fishermen Community. International Journal of Academic Research . May 2014, Vol. 6 Issue 3

Damsar. 2011. Sosiologi Ekonomi. Jakarta: Kencana

Dahuri, R. 2015.Menuju Indonesia Sebagai Poros Maritim Dunia. Bogor: Roda Bahari

Daris, L. Kartika, E.Amanuddin. S. 2012. Dinamika Konflik Dan Peran Kelembagaan Lokal Dalam Pengelolaan Sumberdaya Perikanan Tangkap Di Kabupaten Maros Provinsi Sulawesi Selatan (Jurnal Agrisistem vol 8 no 1, ISSN 2089-0036.

Gunawan, I. 2013. Metode Penelitian Kualitatif, Teori dan Praktik. Jakarta Bumi Aksara.

Hakim, M. 2016. Social Structure and Poverty in the Fishing Community at Pandang-Pandang, Jeneponto in South Sulawesi Province. Mediterranean Journal of Social Sciences MCSER Publishing, Rome-Italy. Vol 7 No 1 S1 January 2016

Hamzah, A. 2008. Respons Komunitas Nelayan Terhadap Modernisasi Perikanan. Tesis IPB. Bogor

Hamzah, A. 2009. Perubahan Struktur Sosial Nelayan Akibat Modernisasi Perikanan. Jurnal Agrisep. Vol 19/3/2009

Hamzah, A. 2013. Transformasi Moda Produksi (Mode Of Production) Masyarakat Pesisir (Studi Kasus Nelayan Bajo di Desa Latawe Kabupaten Muna Provinsi Sulawesi Tenggara). Jurnal Agriplus Vol. 23 No.3.

Hamzah, A. 2017. Institutional Patron - Client Fisherman's in Kampung Bugis District of Poasia Kendari. IOSR Journal Of Humanities And Social Science (IOSR-JHSS) Volume 22, Issue 11, Ver. 7 (November. 2017) PP 32-41 e-ISSN: 2279-0837, pISSN: 2279-0845. www.iosrjournals.org

Hamzah, A, M.Aswar., La Nalefo, A.Gafaruddin. 2015. Fishing Technology Conversion, Differentiation, And Social Mobility Of Fisherman In Lagasa Village Of Muna Regency. IJSTAS Vol: 2 No. 1

Hamzah, A, W. Widayati, Bahtiar., A. Bafadal. 2016. Dynamics of Institutional Patron - Client in Kampung Bugis District of Poasia Kendari. Journal WWJMRD 2015; 2(8).

Hamzah, A, HA Batoa, A Gafaruddin, LK,Arif, 2019.The Dynamic of Institutional Patron-Client (Punggawa-Sawi) of Fishing Community (a Study of Institutional Punggawa-Sawi of Fisherman at Bugis Village, Kendari City). http://gjesr.com/issues \%20PDF/Archive-2010/January-2019/13.pdf

Harini, 2012. Dari Miyang Ke Longlenan: Pengaruh Jaringan Sosial Pada Transformasi Masyarakat Nelayan. Jurnal Komunitas, 4 (2) (2012)

Hasani, Q. 2012. Konservasi Sumber Daya Peikanan Berbasis Masyarakat, Implementasi Nilai Luhur Budaya Indonesia dalam Pengelolaan Sumber Daya Alam. http://jurnal.fp.unila.ac.id/index.php/JPBP/article/ view/18

Hurmain, Puriana. 2013. Transformasi Nelayan di Pesisir Kepulauan Bengkalis (Studi tentang PergeseranPola Interaksi Sosial, Agama, Alat penangkapan dan Perubahan Ekosistem. Jurnal Toleransi, Vol. 5 No. 1

Istiana, T, I Kurniawan. 2014. Entanglement fishermen with middle Man (Case study on Fishermen of gerbang Mekar village, cirebon district, West java) International Researcher Volume No.3 Issue No. 1 March 
Maulana, A. 2014. Hubungan Patron Klien pada Masyarakat Nelayan Desa Kuala Karang Kecamatan Teluk Pakedai Kabupaten Kubu Raya. Jurnal S-1 Sosiologi Volume 3. Nomor 2.

Minaro, S, GN. Ferero, H. Reuter, I. Puten.2016. The role of patron-client relations on the fishing behaviour of artisanal fishermen in the Spermonde Archipelago (Indonesia). Marine Policy vol 69 July 2016.

Mirajiani, E.S Wahyuni, A Satria, Saharuddin, T.Kusumastanto. 2014. Transformasi Pranata Patronase Masyarakat Nelayan: Dari Ekonomi Moralitas Menuju Ekonomi Pasar. Jurnal Komunitas 6 (1) (2014)

Salman, D. 2006. Jagad Maritim. Dialektika Modernitas dan Artikulasi Kapitalisme pada Komunitas Konjo Pesisir di Sulawesi Selatan. Makassar: Ininnawa.

Sugiarto, G, Suryanto. 2014. Peran Kearifan Lokal Sebagai Modal Sosial dalam Penyelesaian Konflik Nelayan di Daerah Kabupaten Situbondo. Jurnal Psikologi Kepribadian dan Sosial Vol. 3 No. 2

Suriadi, A. 2006. Transformasi Industrial Pada Komunitas Nelayan : Studi Kasus di Desa Sei Apung Jaya. Medan: USU Repository.

Susilo, E. 2010. Dinamika Struktur Sosial dalam Ekosistem Pesisir. Malang: UB Press.

Suyuti, N.2011. Orang Bajo di Tengah Perubahan. Jakarta: Penerbit Ombak.

Williams, Chunc (2001), Corporate Social Responsibility : A Theory Of The Firm Perspective, The Academy of Management Review, vol 26, No 1, January 2001 